\title{
Online Teaching of Secondary Vocational Education based on Constructivism
}

\author{
Daozhi Chen*, Jinghui Ling \\ Beijing Union University, Beijing 100101, China \\ *Corresponding author: Daozhi Chen, cdz@buu.edu.cn
}

\begin{abstract}
Online teaching would become a development trend in the field of education. Based on the characteristics of online education and the theory of constructivism, the elements of online teaching would undergo fundamental changes which would certainly lead to revolutionary educational concepts, contents, designs, methods, etc. With the continuous rapid development of China's economy, the scale of vocational education has expanded. In combination with the constructivist learning theory to explain the meaning of online education, analysis of the feasibility of secondary vocational education and their students, as well as the online education in secondary vocational schools, a feasible online teaching design is constructed for vocational teachers. Through research, it is found that the online teaching of secondary vocational education teachers based on constructivism requires improvement in some of their abilities and personal qualities.
\end{abstract}

Keywords: Constructivist learning theory; Secondary vocational education teachers; Online education; Teaching mode

Publication date: July 2021; Online publication: July 30, 2021

\section{Introduction}

With the rapid and sustained development of China's economy as well as the expansion of vocational education, vocational education resources have become an indispensable aspect in the survival and development of enterprises. The Ministry of Education clearly stated that in 2020, the ratio of general high schools' personnel to secondary vocational personnel needs to be 5:5. On February 29, 2020, the communique of the fifth plenary session of the 19th Central Committee of the Communist Party of China also clearly stated, "Build a network power and digital China." It can be appreciated that the online education has the necessary technical support and policy implementation guarantee mechanism in addition to a solid support for the development of online education.

Under the new situation, the online secondary vocational education is conducive to accurately assess the weaknesses of students' academic knowledge, helps to improve learning outcomes, and coordinates online education methods which have become inherent demands in the intense current situation prior stepping into higher education. Secondary vocational education has begun to break the established boundaries of campus and classrooms and has gradually extended outside classrooms. The internet and education are deeply integrated, hence online education operations are formed. Seizing the opportunity for the vigorous development of the online education is both an opportunity and a challenge for secondary vocational education teachers. Discussions are needed among secondary vocational education teachers on how to effectively deal with this aspect and develop it in a healthy and orderly manner. 


\section{Literature review}

\subsection{Online secondary vocational education research}

Relatively speaking, the research on online secondary vocational education in China is still in its preliminary stage. The full text feature and the keyword, "online secondary vocational education" are used to search on HowNet. As of 2020, there are 428 research articles on the themes of online education, primary and secondary schools, online teaching, online learning, online teaching, etc. The earliest literatures among them are from 2009. Due to the outbreak of the epidemic, students in the country studied at home and the online education is used on a large scale. Therefore, the related literature research has rapidly increased and reached a record of 178 in 2020.

In 2019, Professor Nie Yong suggested that the online learning process would strengthen the guidance of teachers, enhance students' classroom participation, establish a sense of autonomous learning, continuously strengthen the external support environment, improve self-management capabilities, and build a home-school collaboration system. In 2020, Zhang Min focused on teachers training, big data awareness, and interactive design to promote the sustainable development of online education. Teachers' training should be conducted to improve their online teaching ability. Second, there is a need to focus on teaching platforms' data as well as to cultivate data management skills. Third, the interaction between students should be focused on in order to enhance the sense of social presence and fourth, there is a need to grasp the characteristics of teaching and learning during the epidemic as well as promote a deeper integration of online education.

\subsection{Constructivist learning theory research}

The classic constructivist learning theory has been explored by Vygosky, Piaget, Bruner, and others. Its core ideas can be summarized into context, collaboration, conversation, and meaning construction. New constructivism is proposed in response to the learning characteristics of the internet age. Its core concept is based on the classic constructivism. "Meaning construction" includes knowledge innovation and combines information overload of the internet age. The characteristics of knowledge fragmentation, etc., therefore have new connotations.

\section{Related concepts and theoretical basis}

The development of online education in secondary vocational schools to a certain extent has aroused people's interests and exploration on online education. In the process of exploring the nature of teaching, online education in secondary vocational education emphasizes more on the exploration of the theory of online education and the need to understand the essential characteristics of education as well as the laws of education and teaching in the unity of theoretical research with learning.

\subsection{Constructivist learning theory}

Constructivism is under the guidance of teachers but at the same time, it involves learner-centered learning. It not only emphasizes the learners' cognitive function but also places importance on the teachers' role in guiding. Teachers are the helpers and supporters in "meaning construction." They are not the imparters and indoctrinators of knowledge. On the other hand, students are the main bodies of information processing and the active constructors of meaning instead of passive recipients and indoctrinated subjects of external stimuli. In order for students to become active constructors of meaning, they are required to play a major role in the learning process from the following aspects. First, using heuristic and discovery methods to construct the meaning of knowledge. Second, students should actively collect and analyze relevant information and materials, propose various hypotheses, and verify the issues in their learning in the process of meaning construction. Third, students need to try connecting their reflections in current learning contents 
with previous knowledge while seriously thinking about this connection.

In short, constructivism is very rich. Simply put, it is student-centered, emphasizes students' active exploration of knowledge, active discovery, and active construction of the meaning of the learned knowledge instead of just acquiring knowledge from the traditional teaching which only involves the transfer from the teachers' minds to the students' notebooks.

\section{Analysis of the academic conditions of secondary vocational schools' students based on the constructivist learning theory}

The key to success of secondary vocational education is to improve the comprehensive ability and quality of secondary vocational schools' students. Hence, there is a need to deeply understand the characteristics of these students.

\subsection{Analysis of the characteristics of secondary vocational schools' students}

Through teaching practices and related research theories, the characteristics of secondary vocational schools' students are summarized below.

\subsubsection{Psychological inferiority complex}

Most of the secondary vocational schools' students have a sense of inferiority in which they feel inferior to others because they did not pass the general high school entrance examination. This is one of their most obvious characteristics. They also have a strong sense of self-denial as they lose interest in learning due to factors such as poor foundation and inappropriate learning methods.

\subsubsection{Rebellious at heart}

Students in secondary vocational schools are in the teenage rebellious phase of rapid psychological development. Their physical and psychological development gradually moves toward adulthood but they do not have enough social experiences to form healthy and complete values or outlook on life.

\subsubsection{Poor adaptability}

It is not easy for secondary vocational schools' students to adjust themselves in adapting to new environments, hence they are more likely to feel lost.

\subsubsection{Active thinking}

Secondary vocational schools' students are in the electronic information age and they receive large amounts of information resources every day which make them actively think. However, they generally dislike school courses and have no enthusiasm for traditional learning.

\subsubsection{Strong self-awareness}

Today's secondary vocational schools' students have strong self-awareness and desires for personal performances as well as to realize their own ideas. Even if students are creative, with poor guidance, they may develop a state of self-centeredness or self-interests.

\subsection{Analysis of the status quo of secondary vocational education}

The survey found that the current classroom teaching methods in secondary vocational schools are 
relatively casual. Either due to inappropriate managements or the poor quality of teachers, teachers do not have the enthusiasm for classroom teachings, the contents of lessons are alike the ones in textbooks, they lack new ideas, and are out of touch with the times. In addition to that, they practice the traditional teaching model of a full classroom teaching in which teachers would explain according to their teaching materials and then set aside time for students to practice operations. Many of the teaching methods proposed in the teaching reform are just gust of wind in which the original teaching model would be restored after some time.

Students' poor enthusiasm in learning which is displayed by them playing games or focusing on other things when they are asked to practice also affects the teachers' enthusiasm for teaching. Students are unwilling to learn while the enthusiasm of teachers is only limited to simple preparations of lectures from textbooks. In this way, students have no interests in learning. This forms a vicious circle in the teaching and learning process.

\subsection{Feasibility of online education in secondary vocational education}

Most of the students' learning interests in secondary vocational schools are generally lacking. They are not interested in the traditional teaching mode, have difficulty concentrating in class, and are impatient with the teaching contents, hence secondary vocational teachers also face the problem in trying to motivate their students. The addition of online education would improve this situation whereby in terms of learning form, this kind of education is more flexible and convenient. Students would be able to deal with learning issues during non-class period, learn at any time and from anywhere, in addition to using fragmented time to learn. In the perspective of learning contents, the knowledge points and learning goals explained in online education are clearer and more purposeful. Online education contents are recorded by teachers in advance before classes and they are from suitable teaching resources found on the internet. Compared with traditional teaching methods, the time for teachers' explanation is saved in online education, hence secondary vocational schools' teachers can use this time to observe students' learning status, completion of homework, problems encountered in learning, etc.

\section{Design and implementation of online teaching by secondary vocational education teachers based on the constructivist education theory}

\subsection{Research and design}

Combining daily information teaching, using online teaching mode, strengthening teaching analysis, and effectively implementing teaching, the following teaching design is proposed as shown in Figure 1.

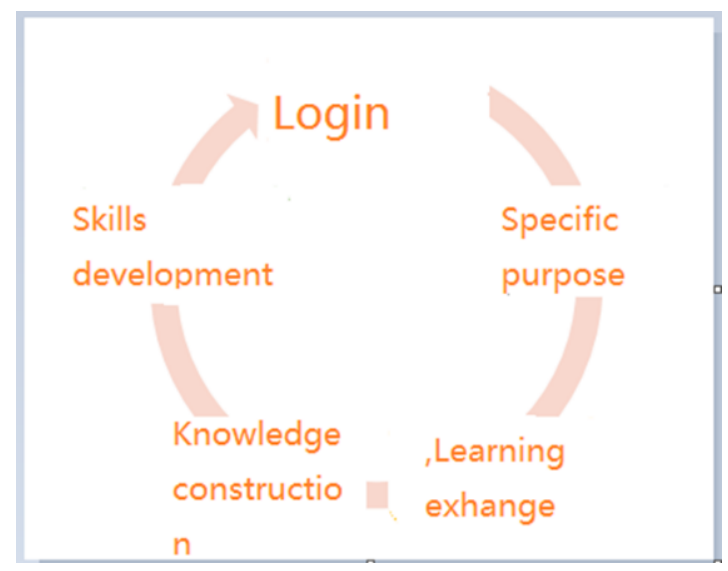

Figure 1. Online teaching design 


\subsection{Research and implementation}

The implementation of online education by secondary vocational education teachers includes five teaching links. The specific course of implementation is shown in Table 1.

Table 1. Online teaching implementation

\begin{tabular}{|c|c|c|c|}
\hline Link & Teachers' teaching behavior & $\begin{array}{c}\text { Students' learning } \\
\text { behavior }\end{array}$ & $\begin{array}{c}\text { Technical support } \\
\text { platform }\end{array}$ \\
\hline Login & $\begin{array}{l}\text { Greetings and welcomes; provide } \\
\text { feedbacks on the participation of } \\
\text { students; clarifying the list of } \\
\text { resources and functions. }\end{array}$ & $\begin{array}{l}\text { Entering into the learning } \\
\text { environment. }\end{array}$ & $\begin{array}{l}\text { Resource sharing } \\
\text { platform, online } \\
\text { teaching service } \\
\text { platform }\end{array}$ \\
\hline $\begin{array}{l}\text { Specific } \\
\text { purpose }\end{array}$ & $\begin{array}{l}\text { Situation introduction; clarifying } \\
\text { tasks including tasks description, } \\
\text { requirements, and outcomes. }\end{array}$ & $\begin{array}{l}\text { Obtain details of tasks } \\
\text { including inspection points } \\
\text { and precautions. }\end{array}$ & $\begin{array}{l}\text { Resource sharing } \\
\text { platform, online } \\
\text { teaching service } \\
\text { platform }\end{array}$ \\
\hline $\begin{array}{l}\text { Learning } \\
\text { exchange }\end{array}$ & $\begin{array}{l}\text { Assign roles or groups; guiding } \\
\text { students learning behaviors; } \\
\text { encouraging discussions and } \\
\text { reflections on teaching activities; } \\
\text { collecting students' questions and } \\
\text { issues faced. }\end{array}$ & $\begin{array}{l}\text { Obtain, browse, and learn } \\
\text { network resources; think, } \\
\text { communicate, and question } \\
\text { among peers or within } \\
\text { groups. }\end{array}$ & $\begin{array}{c}\text { Personalized } \\
\text { platforms such as } \\
\text { online experiment } \\
\text { platform }\end{array}$ \\
\hline $\begin{array}{l}\text { Knowledge } \\
\text { construction }\end{array}$ & $\begin{array}{l}\text { Taking initiative to ask questions } \\
\text { based on students' perplexities } \\
\text { and difficulties; encouraging } \\
\text { reflections; clarify requirements } \\
\text { of jobs or carry out experimental } \\
\text { demonstrations. }\end{array}$ & $\begin{array}{l}\text { Live broadcast participation; } \\
\text { discuss contents of courses; } \\
\text { establishing a connection } \\
\text { between learning contents } \\
\text { and job requirements or try } \\
\text { to experiment; thinking } \\
\text { critically about relevant } \\
\text { contents. }\end{array}$ & $\begin{array}{l}\text { Online live } \\
\text { broadcast platform }\end{array}$ \\
\hline $\begin{array}{l}\text { Skills } \\
\text { development }\end{array}$ & $\begin{array}{l}\text { Becoming helpers and supporters } \\
\text { of students; using live broadcast } \\
\text { system when necessary to provide } \\
\text { feedbacks on tasks completion or } \\
\text { as opportunity for demonstrations; } \\
\text { encourage reflections. }\end{array}$ & $\begin{array}{l}\text { Actively communicate with } \\
\text { teachers and with one } \\
\text { another; adjust knowledge } \\
\text { structure; think and practice } \\
\text { through the connection of } \\
\text { previous knowledge and } \\
\text { new ones; establish new } \\
\text { knowledge structure; strive } \\
\text { to complete tasks; reflect on } \\
\text { learning processes, teaching } \\
\text { resources, and other teaching } \\
\text { links. }\end{array}$ & $\begin{array}{l}\text { Expand internet } \\
\text { resources }\end{array}$ \\
\hline
\end{tabular}




\section{Existing problems and suggested countermeasures}

\subsection{Existing problems}

The students in secondary vocational schools are not only of the same age as those in middle and high schools but they receive more distinctive vocational education. First of all, these students' online education and learning are only aimed at the knowledge points that they are interested in. Secondary vocational education teachers should promote their enthusiasm and initiative for other learnings as well. Secondly, the diversity and adaptation toward online education and learning. To a certain extent, it is difficult for secondary vocational schools' students to adapt quickly. Teachers should make full use of the energetic secondary vocational schools' life and provide students with positive guidance which would promote their interests in learning. Finally, considering that their overall academic performance is not that satisfactory as well as uneven levels among them with the lack of awareness and standardization of knowledge learning and ability improvement, these aspects need to be carried out with supervision from external forces in order to improve the education and teaching level of vocational education. Therefore, the research on these issues do not only signify the theory in educational research that keeps pace with the times but they also have important educational practice values in addition to application values in the online education industry.

\subsection{Suggested countermeasures}

According to the theory of constructivism in regard to online teaching, the knowledge acquired by students is not completely from the teachers' teaching itself but the learners are connected with the media through effective activities, resources, and environment provided by the teacher, that is, in the online teaching environment. Students can fully browse and read various online learning resources then, through the remote online cooperation and guidance from other people including teachers and learning partners, they would challenge their previous knowledge and experiences, hence completing the meaningful construction of knowledge. Therefore, in regard to the online teaching of secondary vocational education based on the constructivist learning theory, teachers should improve some of their abilities and personal qualities.

\subsubsection{Information literacy}

Secondary vocational education teachers should establish the consciousness of lifelong learning, constantly update their knowledge system and abilities, as well as to learn the latest educational theories to ensure the adaptability of their professional skills. The current society is in an era of information explosion. Facing massive amounts of information, teachers should have the skills to correctly interpret and critically evaluate those information, integrate the processing, selecting the essence, and discarding the rest. At the same time, teachers should proficiently use modern information technologies and methods to effectively integrate with the subjects taught so as to improve the quality of classroom teaching and the teaching outcomes.

\subsubsection{Informatization teaching design ability}

Online education is learner-centered in which secondary vocational education teachers need to emphasize on the cultivation of students' ability and their learning processes. Teachers should decide on appropriate teaching models and strategies, implement task-driven and problem-solving methods, as well as stimulate learners' enthusiasm and desire for exploration. In the teaching process, learners are taught to complete the self-construction of knowledge and skills with a variety of learning resources and tools while having the ability to transfer and expand. The informatization teaching design rationally provides effective online and offline interactions, creates contexts, allows learners to be involved in real cognitive experiences, uses flexible and diverse assessment methods, promotes independent learning and teamwork, as well as 
continuously optimize and improve teaching designs.

\subsubsection{Personal qualities}

With online teaching, the influence of teachers on students is no longer restricted to the dimension of a single classroom and physical classes. This requires secondary vocational education teachers to focus on improving personal ethics, strengthening the unity of humanities and science education, as well as the overall development and cultivating their personality. Secondly, teachers need to constantly reflect on themselves in their own practices because teaching has no fixed method and students differ from one another, hence teachers must be innovative. Finally, in order to reach a state of excellence, teachers need to redirect their consciousness of their roles while using the latest and best theories to carry out teaching reforms and innovations.

\section{Conclusion}

In view of the "Internet +" education, secondary vocational education teachers should make good use of online education resources along with the development trends of education as well as to better understand and use these resources to improve the willingness and efficiency of secondary vocational schools' students in learning. In this way, it promotes the construction of a secondary vocational school in the new era in which colleges and universities innovate online education to provide meaningful references.

\section{Funding}

Supported by Beijing Youth Teaching Teacher Project "Research on the Sense of Presence of Online Education under the Background of Mobile Internet" (Item Number: 12205561110-506).

\section{Disclosure statement}

The authors declare that there is no conflict of interest.

\section{References}

[1] Zhou X, Shi H, 2020, How College Teachers Develop Online Teaching based on Constructivist Education Theory. Knowledge Economy, 000(010): 135-6.

[2] Pang N, Research on the Application of "Micro-Class Circle" in Secondary Vocational Computer Courses under the Internet + Education Perspective. Hebei Normal University.

[3] Ma Z, Research on the Status Quo and Teaching Mode of Online Education Outside of Primary and Secondary Schools. Beijing University of Posts and Telecommunications.

[4] Liu Y, 2017, Research on the Willingness to Use Mobile Learning of Secondary Vocational Students based on TAM and SEM. Hebei Normal University.

[5] Wang Z, 2011, New Constructivism: Learning Theory in the Internet Age. Journal of Distance Education, 29(02): 11-8.

[6] Yu S, 2000, Research and Implementation of Network Teaching Support System. Beijing Normal University. 